\title{
Localised pulmonary resection for bronchiectasis in hypogammaglobulinaemic patients
}

\author{
Andrea J Cohen, Chaim Roifman, J Brendan M Mullen, Brenda Reid,
} Gordon Weisbrod, Gregory P Downey

\begin{abstract}
Background - Bronchiectasis and pulmonary infections are common in patients with hypogammaglobulinaemia. Despite intravenous gammaglobulin treatment and appropriate antibiotics, $a$ subgroup of patients remains with persistent localised pulmonary infection in segments where bronchiectasis had developed before appropriate treatment. As such localised pulmonary suppuration (segmental or lobar) may serve as a focus for progression of bronchiectasis, surgical resection of the involved segments may be considered. The outcome of pulmonary resection in four such patients is reported.
\end{abstract}

Results - Surgery was well tolerated except for one postoperative empyema. Information on follow up is available from 3.5 to 5 years. All patients expertoms including cough, sputum production, antibiotic use, and hospital admissions.

Conclusions - Surgical resection of localised bronchiectatic segments should be considered in patients with hypogammaglobulinaemia with persistent localised suppuration and symptoms refractory to medical treatment.

(Thorax 1994;49:509-510)

Department of Pediatrics, Division of Immunology and Allergy

C Roifman

B Reid

Department of Pathology

J B M Mullen

Department of Radiology

G Weisbrod

The University of Toronto, Toronto, Ontario, Canada M5G 2C4

Reprint requests to: Dr G P Downey.

Received 13 April 1993 Returned to authors 16 July 1993

Revised version received 27 January 1994

Accepted for publication

1 February 1994

Bronchiectasis and pulmonary infections are common in patients with hypogammaglobulinaemia. ${ }^{12}$ High dose intravenous gammaglobulin administration results in physiological circulating levels of inmunoglobulins and thus patients on this therapy should be fully immunocompetent. ${ }^{3-6}$ Indeed, such patients have fewer pulmonary infections and show considerable improvement. ${ }^{67}$ However, some patients, particularly those who have developed bronchiectasis before treatment of their immunodeficiency state, have persistent localised pulmonary infection and refractory symptoms.

Surgical resection used to be a common means of attempting to control symptoms and preventing spread of bronchiectasis by eradication of suppuration in truly localised areas. ${ }^{8-10}$ ienced considerable reduction of symp-

Today surgical resection is rarely attempted unless medical treatment has failed even in immunocompetent patients. ${ }^{112}$ Resection is not generally considered appropriate for patients with bronchiectasis resulting from hypogammaglobulinaemia or ciliary dysformation because of the high probability of recurrence. ${ }^{12}$ However, patients with hypogammaglobulinaemia receiving intravenous gammaglobulin replacement therapy should be fully immunocompetent and perhaps more suitable for resection of localised disease. We describe four patients who, despite aggressive medical treatment (intravenous gammaglobulin replacement, physiotherapy, and broad spectrum antibiotics), had persistent pulmonary infection with localised bronchiectasis who underwent successful lobectomy.

\section{Methods}

\section{PATIENT SELECTION}

Four of 65 patients with hypogammaglobulinaemia followed at the Immunology Clinic at the Hospital for Sick Children were considered for surgery on the following criteria: (1) documented panhypogammaglobulinaemia despite monthly intravenous gammaglobulin replacement; (2) persistent or recurrent pulmonary infections unresponsive to antibiotic therapy; and (3) localised bronchiectasis involving one lobe only as demonstrated by high resolution computed tomographic (CT) scanning.

All patients were receiving monthly intra-

\section{Results}

The cases are summarised in the table. The first case is presented in more detail to illustrate the clinical course of a representative patient. 
Summary of patients

\begin{tabular}{|c|c|c|c|c|c|c|}
\hline \multirow[b]{2}{*}{$\begin{array}{l}\text { Patient } \\
\text { no. }\end{array}$} & \multirow[b]{2}{*}{$\begin{array}{l}\text { Current age } \\
\text { (years) }\end{array}$} & \multicolumn{2}{|l|}{ Before surgery } & \multicolumn{2}{|l|}{ After surgery } & \multirow{2}{*}{$\begin{array}{l}\text { Length of } \\
\text { follow up } \\
\text { (months) }\end{array}$} \\
\hline & & Symptoms & Lab testing & $\begin{array}{l}\text { Surgery } \\
\text { complications symptoms }\end{array}$ & Lab testing & \\
\hline 1 & 15 & $\begin{array}{l}\text { Cough }+++ \\
\text { Sputum }+++ \\
\text { Purulent } \\
\quad \text { exacerbations }+++\end{array}$ & $\begin{array}{l}\text { PFTs: FVC } 100 \%, \mathrm{FEV}_{1} \\
103 \% \\
\text { CT: RML bronchiectasis }\end{array}$ & $\begin{array}{l}\text { RML lobectomy } \\
\text { No complications } \\
\text { Cough }+ \\
\text { Sputum }+ \\
\text { Purulent exacerbations }+\end{array}$ & $\begin{array}{l}\text { PFTs: FVC } 106 \%, \mathrm{FEV}_{1} 97^{\circ} \% \\
\mathrm{CT} \text { : no bronchiectasis, } \\
\text { mild bronchial thickening LLL }\end{array}$ & 48 \\
\hline 2 & 9 & $\begin{array}{l}\text { Cough }+++ \\
\text { Sputum }+++ \\
\text { Purulent } \\
\quad \text { exacerbations }+++\end{array}$ & $\begin{array}{l}\text { PFTs: FVC } 99 \%, \mathrm{FEV}_{1} \\
109 \% \\
\text { CT: LLL bronchiectasis, } \\
\text { atelectasis, and consolidation }\end{array}$ & $\begin{array}{l}\text { LLL lobectomy } \\
\text { No complications } \\
\text { Cough }+ \\
\text { Sputum }+ \\
\text { Purulent exacerbations }+\end{array}$ & $\begin{array}{l}\text { PFTs: FVC } 92 \%, \text { FEV } 101 \% \\
\text { CT: no bronchiectasis, } \\
\text { bronchial wall thickening RLL }\end{array}$ & 43 \\
\hline 3 & 28 & $\begin{array}{l}\text { Cough }+++ \\
\text { Sputum }+++ \\
\text { Purulent } \\
\quad \text { exacerbations }+++\end{array}$ & $\begin{array}{l}\text { PFTs: FVC } 57 \%, \mathrm{FEV}_{1} 57 \% \\
\mathrm{Po}_{2} 10.9 \mathrm{kPa} \\
\mathrm{CT}: \text { LLL bronchiectasis, } \\
\text { mild RLM bronchial dilation }\end{array}$ & $\begin{array}{l}\text { LLL lobectomy } \\
\text { Complication: empyema } \\
\text { Cough }+ \\
\text { Sputum }+ \\
\text { Purulent exacerbations }+ \\
\text { Two successful pregnancies }\end{array}$ & $\begin{array}{l}\text { PFTs: FVC } 45 \%, \mathrm{FEV}_{1} 43 \% \\
\mathrm{PO}_{2} 10.5 \mathrm{kPa} \\
\mathrm{CT}: \text { left sided pleural } \\
\text { thickening, RML and LUL. } \\
\text { bronchial dilation }\end{array}$ & 72 \\
\hline 4 & 39 & $\begin{array}{l}\text { Cough }+++ \\
\text { Sputum }+++ \\
\text { Purulent } \\
\quad \text { exacerbations }+++\end{array}$ & $\begin{array}{l}\text { PFTs: FVC } 96 \%, \text { FEV } 190 \% \\
\text { CT:LLL bronchiectasis }\end{array}$ & $\begin{array}{l}\text { LLL lobectomy } \\
\text { No complications } \\
\text { Cough }+ \\
\text { Sputum }+ \\
\text { Purulent exacerbations }+\end{array}$ & $\begin{array}{l}\text { PFTs: FVC } 92 \%, \mathrm{FEV}_{1} 88^{\circ}, \\
\text { CT: mild cylindrical } \\
\text { bronchiectasis of lingula }\end{array}$ & 42 \\
\hline
\end{tabular}

$\mathrm{CT}=$ computed tomographic scan of chest $\mathrm{RML}=$ right middle lobe; $\mathrm{LLL}=$ left lower lobe; PFTs = pulmonary function testing reported as percentage predicted normalised for age.

normalised for age.

Cough: + mild; ++ moderate; +++ frequent and severe.
Sputum: $+\leqslant 2$ tbsp/day; $++>2$ tbsp/day; $+++>1 / 2$ cup day

Purulent exacerbations (required antibiotics): $+<1$ year; $++2-6$ year; $+++>6$ year.

CASE 1

A one year old boy with recurrent infections was diagnosed as having acquired hypogammaglobulinaemia. Treatment was initiated with intramuscular gammaglobulin replacement but frequent infections of the eyes, nose and chest continued. At 9 years intravenous gammaglobulin therapy was commenced with a decrease in ocular and nasal infections, but cough productive of purulent sputum continued with right middle lobe consolidation and atelectasis. High resolution chest CT scanning indicated bronchiectasis limited to the right middle lobe and, at 11 years, right middle lobectomy was performed without complication. Postoperatively there was a significant diminution of sputum production and cough. Four years after surgery he continued to have minimal pulmonary symptoms, and results of pulmonary function tests were within normal limits. Chest CT scanning demonstrated mild peribronchial thickening in the right lower lobe which had not progressed in more than one year.

\section{Discussion}

In each of the cases resection of a localised bronchiectatic segment caused a considerable diminution of symptoms, requirement for antibiotic therapy, need for medical care, and improvement in the quality of life. The lobectomies were physiologically well tolerated with the exception of case 3 who developed an empyema which rapidly resolved with appropriate therapy. Our experience suggests that surgical resection of localised bronchiectasis should be considered in patients with hypogammaglobulinaemia who have continued to have symptoms refractory to conventional medical therapy including gammaglobulin replacement. All our patients have progressed to develop bronchial thickening in previously unaffected segments as seen by high resolution CT scanning, and whilst the clinical significance of these abnormalities is uncertain, it is possible that bronchiectasis might develop in these areas. Based on the rate of progression of symptoms preoperatively, it is possible that bronchiectasis may have developed in additional areas even if surgical resection had not been undertaken. Only case 4 has developed obvious bronchiectasis which is cylindrical, limited to one segment of the lingula, and has not progressed further in the three years of follow up. The improvement seen in the four patients following their resections has continued for $3 \cdot 5-5$ years.

This work was supported by operating grants from the Medical Research Council of Canada (GD), the Ontario Thoracic Society (GD), the National Cancer Institute of Canada (CR), and the Reichman Foundation for Immunodeficiency.

1 Marcy TW, Reynolds HY. Pulmonary consequences of congenital and acquired primary immunodeficiency states. Clin Chest Med 1989; 10:503-19.

2 Barker AF, Bardana JR. State of the art: bronchiectasis; update of an orphan disease. Am Rev Respir Dis 1988;137:969-78.

3 Dwyer JM. Thirty years of supplying the missing link History of gammaglobulin therapy for immunodeficient states. Am $\mathcal{F}$ Med 1984;76(Suppl 3a):46-52.

4 Long AA, Denburg JA, Dent PB. Hypogammaglobulinaemia: therapeutic rationale. Can Med Assoc $f$ 1987; 137:793-7.

5 Dukes RJ, Rosenow EC, Hermans PE. Pulmonary manifestations of hypogammaglobulinaemia. Thorax 1978;33:603-7.

6 Roifman CM, Levinson H, Gelfand EW. High versus low dose intravenous immunoglobulin in hypogammaglobudose intravenous immunoglobulin in hypogammaglobu-
linemia and chronic lung disease. Lancet 1987;i:1075-7.

7 Roifman CM, Lederman HM, Lavi S, Stein LD, Levenson $\mathrm{H}$, Gelfand EW. Benefit of intravenous IgG replacement $\mathrm{H}$, Gelfand EW. Benefit of intravenous IgG replacement in hypogammaglobulinemic patients in chronis

8 Campbell DM, Lilly JR. The changing spectrum of pulmonary infections in infants and children. $\mathcal{F}$ Thorac Cardiovasc Surg 1982;83:680-5.

9 Ochner A. The development of pulmonary surgery with special emphasis on carcinoma and bronchiectasis. $\mathrm{Am} \mathcal{J}$ Surg 1978;135:732-46.

10 Annest LS, Kratz, Crawford FA. Current results of treatment of bronchiectasis. $\mathcal{f}$ Thorac Cardiovasc Surg 1982;83:546-50.

11 Weg JG. Bronchiectasis. Semin Respir Med 1992;13:177-89.

12 Hood RM. Bacterial diseases of the lung. In: Shields TW, ed. General thoracic surgery. 3rd edn. Philadelphia, Lea and Febiger, 1989:750-71. 